\title{
SEORANG WANITA DENGAN ASPIRASI JARUM PENTUL HARI KE-14
}

\author{
${ }^{1}$ Mohammad Subkhan, ${ }^{1}$ Isnu Pradjoko \\ ${ }^{1}$ SMF Ilmu Penyakit Paru \\ FK UNAIR/RSU dr. Soetomo
}

\author{
Email : irfanalaily@gmail.com
}

\begin{abstract}
ABSTRAK
Aspirasi benda asing merupakan masalah global dan seringkali menyebabkan komplikasi yang mengancam jiwa, Aspirasi benda asing lebih sering terjadi pada anak-anak dibanding orang dewasa. Sekitar 75\% sampai 85\% aspirasi benda asing terjadi pada anak dibawah 15 tahun yang lebih dari dua pertiga kasus terjadi pada anak-anak usia dibawah tiga tahun (3). Di Amerika angka kematian pada anak usia di bawah 4 tahun mencapai 7\% pada tahun $1986^{(5)}$. Pada kasus ini, penderita adalah seorang perempuan berumur 14 tahun, datang ke IRD dikonsulkan ke bagian paru dengan keluhan tertelan jarum pentul saat sedang memakai hijab sambil bercanda dengan temannya. Kemudian dilakukan foto Rontgen tampak bentukan metal jarum di daerah parakardial kanan Pada dewasa bronkus utama kanan lebih pendek dari bronkus utama kiri. Bronkus utama kanan membentuk sudut 25 derajat dari garis median, sedangkan bronkus utama kiri membentuk sudut 45 derajat. Pada anak usia dibawah 14 tahun hal ini tidak berlaku karena ukuran bronkus kanan dan kiri relatif sama, dengan percabangan bronkus kiri tidak sedekat pada bronkus kanan. Selanjutnya dilakukan ekstraksi jarum pentul yang telah teraspirasi dengan menggunakan bronkoskopi serat optik pada penderita. Ekstraksi jarum pentul berhasil dilakukan dengan baik.
\end{abstract}

Kata Kunci : Aspirasi, ekstraksi jarum pentul

\section{ABSTRACT}

Foreign body aspiration is a global problem and often causes life-threatening complications, foreign body aspiration is more common in children than adults. Approximately 75\% to 85\% of foreign body aspiration occurs in children under 15 years of age who are more than two thirds of cases occurring in cbildren under three years of age (3). In America the mortality rate for children under the age of 4 reached $7 \%$ in 1986 (5). In this case, the patient was a 14-year-old woman, came to IRD to be consulted to the lungs with complaints of swallowing a pin while wearing a bijab while joking with her friend. X-rays were then performed showing metal needle formation in the right parakardial area. In adults the right main bronchus is shorter than the left main bronchus. The right main bronchus forms an angle of 25 degrees from the median line, while the left main bronchus forms a 45 degree angle. In children under 14 years of age this is not valid because the size of the right and left bronchi is relatively the same, with the branching of the left bronchus not as close to the right bronchus. Then extraction of pentuled needles was carried out using fiber optic bronchoscopy in patients. The extraction of the pin needle was done well.

KeyWord : aspiration, extraction of pentuled needles 


\section{PENDAHULUAN}

Aspirasi benda asing merupakan masalah global dan seringkali menyebabkan komplikasi yang mengancam jiwa. Benda asing dapat berasal dari luar tubuh maupun dalam tubuh. Benda asing yang berasal luar dari tubuh disebut benda asing eksogen, seperti kacang-kacangan, tulang serta zat anorganik seperti paku, jarum, peniti, batu dan lain-lain dan yang dari dalam tubuh disebut benda asing endogen, seperti gigi yang terlepas. (D. Passàli, 2010. Nael Al-Sarraf, 2009, Ahmed Ragab, 2007. Warshawsky EM., 2006)

Aspirasi benda asing lebih sering terjadi pada anak-anak dibanding orang dewasa. Sekitar 75\% sampai $85 \%$ aspirasi benda asing terjadi pada anak dibawah 15 tahun, dimana lebih dari dua pertiga kasus terjadi pada anak-anak usia di bawah tiga tahun. Di Amerika, didapatkan data kematian pada anak usia dibawah 4 tahun sebesar $7 \%$ di Amerika pada tahun 1986. (Dikensoy O, 2002) Shivakumar dkk di India menulis rata-rata kasus kematian karena aspirasi benda asing $0-1,8 \%{ }^{(2)}$. Kasus ini akan membahas aspirasi benda asing pada penderita 14 tahun.

Benda asing dapat menimbulkan obstruksi parsial ataupun total. Gejala meliputi batuk kronis, hemoptisis, panas badan, sesak napas, nyeri dada, perasaan tercekik, maupun wheezing. Apabila diagnosa dan penanganan terhadap aspirasi benda asing terlambat ditegakkan, komplikasi seperti pneumonitis obstruksi, atelektasis, bronkiektasis dan abses paru dapat terjadi. Pengetahuan tentang penegakan diagnosa, dan penatalaksanaan yang tepat dapat membantu penderita dan mengurangi komplikasi diatas.(Ahmed Ragab, 2007, Dikensoy O, 2002)

Pada kasus berikut ini akan dilaporkan seorang remaja dengan aspirasi jarum pentul pada paru kiri hari keempat belas, dengan terapi bronkoskopi (FOB).

\section{KASUS}

\section{Data dasar}

1. Identitas penderita

$\begin{array}{lll}\text { Nama } & \text { Nn. N } \\ \text { Umur } & \text { : } & 14 \text { tahun } \\ \text { Jenis kelamin: } & \text { Perempuan } \\ \text { Suku } \quad: & \text { Madura }\end{array}$

Agama : Islam

Pendidikan : SMP

Pada tanggal 16 Juli 2010 penderita datang ke IRD dikonsulkan ke bagian paru, Penderita datang dengan keluhan tertelan jarum pentul, penderita dirujuk dari spesialis paru.

2. Keluhan utama : Tertelan jarum pentul

3. Riwayat penyakit sekarang

Tertelan jarum pentul dialami pada tanggal 2 Juli 2010. Saat itu penderita hendak memakai jilbab di sekolah sambil bercanda dengan temantemannya, jarum pentul digigit, ketika penderita tertawa jarum pentul tertelan. Sesaat ketika tertelan, penderita merasakan batuk-batuk hebat, namun satu jam setelah itu penderita merasa keluhan sudah berkurang, karena takut penderita tidak periksa ke dokter terdekat selain karena alasan biaya, selang 14 hari atas bujukan keluarga penderita akhirnya penderita berani periksa ke praktek spesialis paru, karena keterbatasan alat di puskesmas, penderita di rujuk ke RSUD Dr SOETOMO. Keluhan sesak napas maupun panas badan tidak didapatkan.

4. Riwayat penyakit dahulu

Tidak didapatkan riwayat penyakit asma maupun darah tinggi

5. Riwayat sosial dan budaya

Tidak didapatkan riwayat kontak dengan penderita TB paru. Tidak didapatkan riwayat keluarga dengan tumor.

6. Pemeriksaan fisik

Saat MRS tanggal 16 Juli 2010 didapatkan penderita sebagai berikut:

a. Keadaan umum

Baik, kesadaran kompos mentis, TB 154 $\mathrm{cm}, \mathrm{BB} 42 \mathrm{Kg}$

Tekanan darah : 110/70 mmHg, nadi : 80 $\mathrm{x} / \mathrm{mnt}$, pernafasan $18 \mathrm{x} / \mathrm{mnt}$, temperatur aksila : $36,7^{\circ} \mathrm{C}$.

b. Pemeriksaan kepala dan leher

Konjungtiva tidak pucat, sklera tidak ikterus, mukosa tidak sianotik, tidak sesak, tekanan vena jugularis tidak meningkat, tidak kaku kuduk, tidak didapatkan pembesaran kelenjar getah bening. 
c. Pemeriksaan dada

Jantung : iktus kordis tidak tampak, pulsasi tidak tampak, pulsasi jantung tidak teraba, thrill tidak ada, batas kanan mid sternal line ICS II kanan, batas kiri linea medio klavikularis sinistra ICS VI, suara jantung 1 dan 2 tunggal, murmur tidak ada, ekstra sistolik tidak ada.

Paru : Inpeksi : bentuk dan pergerakan simetris

Palpasi : pergerakan simetris

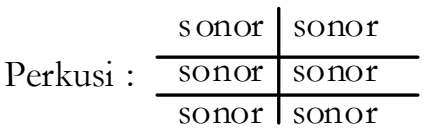

Auskultasi : suara nafas paru kiri dan paru kanan normal, tidak terdapat suara tambahan.

d. Pemeriksaan perut

Perut tampak datar, tidak terdapat kolateral, hepar dan lien tidak teraba, suara bising usus normal, tidak teraba massa.

e. Pemeriksaan anggota gerak

Tidak didapatkan edema maupun jari tabuh, tidak teraba pembesaran kelenjar getah bening didaerah lipat paha dan ketiak.

7. Pemeriksaan penunjang

Toraks PA/ lateral kanan (17 Juli 2010) :

Cor : Ukuran dan bentuk normal

Pulmo : Tampak bentukan metal jarum di daerah parakardial kiri. Tak tampak infiltrat. Kedua sinus kostofrenikokostalis tajam. Pada gambaran foto lateral kanan tampak bentukan metal jarum pada paru lobus inferior kanan.

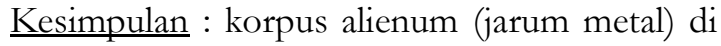
daerah cabang bronkus kiri.

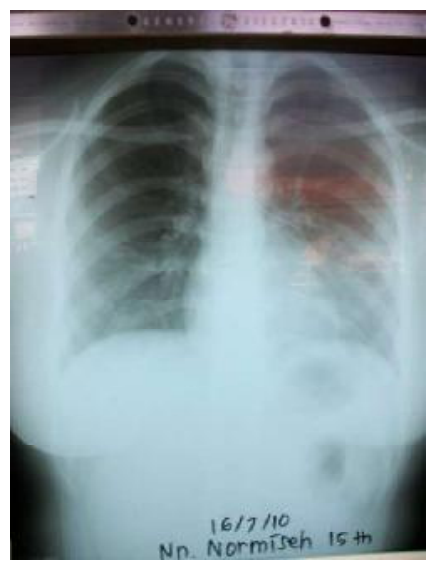

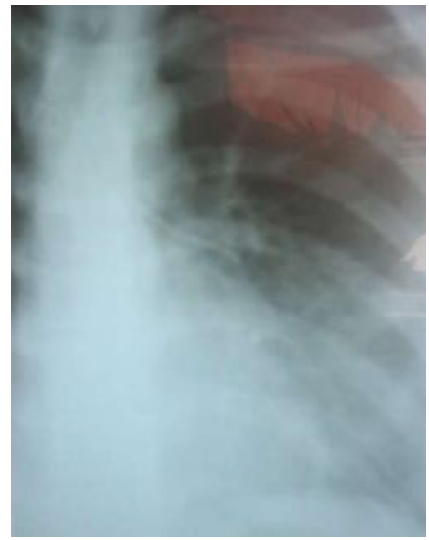

\section{DAFTAR MASALAH}

Daftar masalah sementara

1) Tertelan jarum pentul

Tertelan jarum pentul dialami pada tanggal 2 Juli 2010. Saat itu penderita hendak memakai jilbab di sekolah sambil bercanda dengan temantemannya, jarum pentul digigit, ketika penderita tertawa jarum pentul tertelan. Sesaat ketika tertelan, penderita merasakan batuk-batuk hebat, namun satu jam setelah itu penderita merasa keluhan sudah berkurang, karena takut penderita tidak periksa ke dokter terdekat selain karena alasan biaya, selang 14 hari atas bujukan keluarga penderita akhirnya penderita berani periksa ke praktek spesialis paru, penderita di rujuk ke RSUD Dr SOETOMO. Keluhan sesak napas maupun panas badan tidak didapatkan.

2) Abnormal Pemeriksaan Fisik : -

3) Abnormal Laboratorium : -

4) Abnormal foto toraks : jarum metal pada percabangan bronkus kiri.

\section{Sequence of Event}

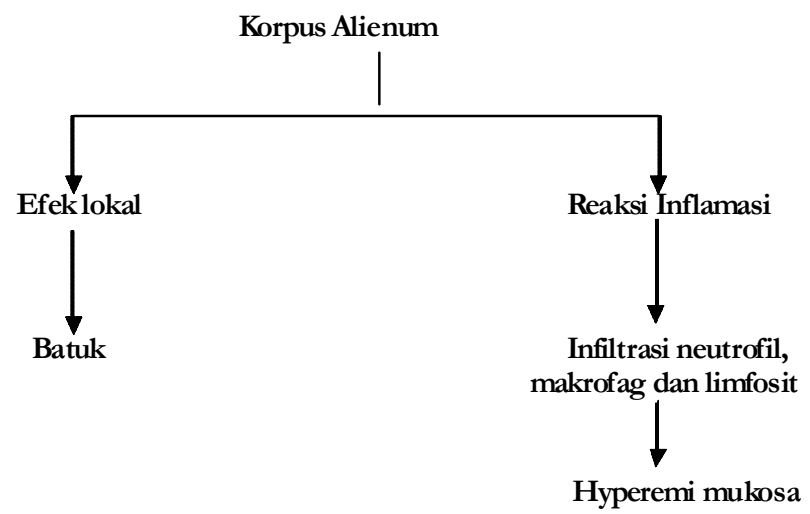


Daftar masalah tetap

1) Tertelan jarum pentul

2) Korpus alienum (jarum metal) paru kiri

\section{ANALISA MASALAH}

\begin{tabular}{|l|l|l|l|}
\hline Analisis & Plan Dx & Plan Tx & Plan Mx \\
\hline $\begin{array}{l}\text { 1) Tertelan } \\
\text { jarum pentul } \\
\begin{array}{l}\text { 2) Korpus } \\
\text { alienum paru kiri }\end{array}\end{array}$ & $\begin{array}{l}\text { Sesuai no 2 } \\
\text { Faal paru } \\
\text { Konsul } \\
\text { kardiologi } \\
- \text { FOB }\end{array}$ & $\begin{array}{l}\text { Sesuai nomor } \\
\text { FOB untuk } \\
\text { ekstraksi } \\
\text { korpus } \\
\text { alienum }\end{array}$ & vs/ klinis \\
& & \\
\hline
\end{tabular}

CATATAN PERJALANAN PENYAKIT

Tanggal 16 Juli 2010

$\mathrm{S}$ : batuk (-), nyeri dada (-)

$\mathrm{O}$ : komposmentis, $\mathrm{T}$ : 110/70 $\mathrm{mmHg}, \mathrm{N}: 80 \mathrm{x} \mathrm{m}$,

RR : $21 \mathrm{x} / \mathrm{mnt}$, t. aksila : $36,7^{\circ} \mathrm{C}$

Kepala : konjungtiva pucat -/- sklera ikterik -/ - mukosa sianotik-/-

Leher : tidak didapatkan pembesaran kelenjar getah bening dan peningkatan JVP

Thoraks :

Jantung : suara jantung 1,2 tunggal, tidak didapatkan murmur

Paru : simetris, tidak ditemukan ronki maupun wheering

Abdomen : supel, tidak teraba pembesaran hepar maupun lien.

Ekstremitas : tidak didapatkan edema maupun jari tabuh

Pemeriksaan laboratorium (16 juli 2010)

$\mathrm{Hb}: 12,2 \mathrm{~g} / \mathrm{dL} \quad$ SGOT $: 14$ Alb : 4,3

Leko : 8,6. 103/uL SGPT : 14

Trombo : 409. $10^{3} / \mathrm{uL}$ BUN : 9

HCT : 35,1 \% SK : 0,67

Pemeriksaan Faal Hemostasis (16 Juli 2010)

PPT $\quad: 16,9$ APPT : 30,3

Kontrol : 17.6 Kontrol: 32,0

Kesan : normal

Hasil BGA (16 Juli 2010)

$\begin{array}{ll}\mathrm{pH} & : 7,41 \\ \mathrm{pCO}_{2} & : 37 \mathrm{mmHg}\end{array}$

$$
\begin{array}{ll}
\mathrm{pO}_{2} & : 94 \mathrm{mmHg} \\
\mathrm{HCO}_{3} & : 23,5 \mathrm{mmol} / 1 \\
\mathrm{BE} & :-1,1 \mathrm{mmol} / 1 \\
\text { Sat O2 } & : 97 \%
\end{array}
$$

Konsul kardiologi (16 Juli 2010):

Irama sinus, HR 80x/menit. Aksis normal.

Kesimpulan : saat ini di bidang kardiologi kami dapatkan pemeriksaan pasien tidak ada kelainan, dengan cardiac risk index I.

Pemeriksaan faal paru (16 Juli 2010) :

\begin{tabular}{|l|l|l|l|}
\hline Faal paru & Subyek & Prediktet & $\%$ \\
\hline VC & 2020 & 2530 & 79,84 \\
FVC & 2100 & 2293 & 83,00 \\
FEV & 2100 & 2100 & 100 \\
MBC & 84,24 & 83,41 & 100,9 \\
& & & \\
\hline
\end{tabular}

Kesimpulan : tidak ada restriksi maupun obstruksi

\section{Tanggal 19 Juli 2010}

S : batuk dan nyeri dada tidak didapatkan

O : TD : 120/70 mmHg, N:88 x/mnt, RR: 18 x/ mnt, Temp. aksila: $36^{\circ} \mathrm{C}$

Dilakukan FOB (19 Juli 2010)

FOB dilakukan di OK Paru dengan double set up di OK IRD, apabila ekstraksi FOB gagal, akan dilakukan torakotomi oleh sejawat bedah. Diberikan anestesi dormicum

FOB : Plika vokalis gerakan simetris, trakea lumen bulat, mukosa hoperemi, karina utama tajam.

Tampak corpal jarum pentul di karina utama dengan pangkal di distal, penderita batuk jarum pentul menuju ke trakea dan jatuh melalui bronchus utama kanan dan berhenti pada lobus medius dengan pangkal di distal.

Jarum pentul berhasil diekstraksi dengan forcep. Post ekstraksi tidak didapatkan laserasi dan perdarahan pada lobus medius.

Paru kiri : Tidak dilakukan evaluasi

Hasil roentgen toraks post ekstraksi (20 Juli 2010)

Kesimpulan : tak tampak kelainan

A : Post ekstraksi korpus alienum jarum pentul di karina utama

PDx dan PTx : -

Tanggal 20 Juli 2010 : penderita dipulangkan. 


\section{PEMBAHASAN}

Pada dewasa bronkus utama kanan lebih pendek dari bronkus utama kiri. Bronkus utama kanan membentuk sudut 25 derajat dari garis median, sedangkan bronkus utama kiri membentuk sudut 45 derajat. Dengan demikian bronkus utama kanan hampir membentuk garis lurus dengan trakea, sehingga benda asing dari luar yang masuk kedalam bronkus akan lebih mudah masuk ke dalam bronkus kanan, bila dibandingkan dengan bronkus kiri. Pada anak hal ini tidak berlaku karena ukuran bronkus kanan dan kiri relatif sama, dengan percabangan bronkus kiri tidak sedekat pada bronkus kanan.

Pada penderita yang berusia 14 tahun (termasuk dalam usia anak-anak), benda asing didapatkan pada bronkus kiri yang masuk saat menggigit jarum pentul sambil berbicara kemudian merasa tertelan, penderita mengalami batuk-batuk keras sebentar, namun satu jam setelah itu penderita tidak mengeluh apapun.

Pada dewasa, aspirasi benda asing kebanyakan terjadi karena penurunan mekanisme proteksi jalan nafas seperti intoksikasi alkohol, susunan gigi yang buruk, penggunaan sedativa, retardasi mental, gangguan neurologis, trauma dengan penurunan kesadaran dan general anestesi. Keadaan tertentu seperti tertawa, menangis, bersin dapat juga menyebabkan aspirasi benda asing.

Kebanyakan benda asing yang diaspirasi bahan organik seperti kacang dan biji-bijian (pada anak) serta bahan makanan dan tulang (pada dewasa). Adapun bahan inorganik, yang sering pada anak misalnya koin, pin, bagian dari mainan dan bagian-bagian kecil dari peralatan sekolah, sedang pada dewasa misalnya gigi palsu, pil, serta pin atau jarum penutup kepala/jilbab (sering pada wanita muslim). Bahan organik dapat menyebabkan inflamasi mukosa yang lebih berat dengan jaringan granulasi yang terbentuk dalam beberapa jam. Bahan-bahan tertentu seperti biji-bijian, kedelai, jagung dapat mengasorbsi air dan membengkak sehingga dapat menyebabkan obstruksi jalan nafas parsial hingga total. Bahan inorganik dengan ukuran kecil dapat tidak memberikan gejala dalam waktu lama, kecuali menyebabkan obstruksi total jalan nafas.

Pada penderita, benda asing yang diaspirasi berupa jarum pentul yang berfungsi sebagai pengait jilbab, termasuk bahan inorganik metal dan sebagian plastik dan karena ukurannya kecil sehingga tidak memberikan gejala meskipun dalam waktu lama, dalam kasus ini sampai 14 hari.

Derajat gejala dapat bervariasi sesuai letak pada bronkus. Oklusi pada laring dengan ukuran aspirat yang besar dapat memberi gejala yang akut, bila aspirat melewati plika vokalis menuju area subglotis/trakea, gejala batuk dengan stridor inspiratoir dapat ditemukan. Bila aspirat menuju bronkus yang lebih dalam, periode asimtomatik sering terjadi. Batuk merupakan mekanisme perlindungan paru dari aspirasi dan membantu pengeluaran sekresi bronkial yang berlebih. Batuk dapat terjadi karena rangsangan pada reseptor iritan yang terdapat pada laring, trakea dan bronkus besar.

Pada penderita ini didapatkan aspirat benda asing karina utama, sama sekali tidak memberikan gejala seperti batuk atau gejala yang lain.

Paru-paru dipelihara dalam kondisi stabil dengan adanya replacement dari sel-sel tua. Dalam kondisi trauma, dapat terjadi respons inflamasi dan terjadi aktivasi cascade dimana terjadi regenerasi formasi jaringan. Dimulai dengan infiltrasi neutrofil, diikuti makrofag dan limfosit. Sel makrofag yang teraktifasi memproduksi mediator-mediator yang sesuai untuk menstimulasi inflamasi dan proses regenerasi sel, terdiri dari sel yang bertanggung jawab pada awal inflamasi (proinflamatory) cytokines, yang beberapa diantaranya adalah chemotactic factors (chemokines). Chemotactic factors menarik leukosit dan sel-sel mesenkimal (fibroblast, sel otot polos dan endothelial sel) menuju lokasi injury dan memulai proses fibrosis. Fibrotic cytokines mencetuskan proliferasi fibroblast dan menstimuli produksi dari conective tissue. Leukosit memproduksi mediator-mediator seluler (sitokin) yang memicu proliferasi sel kapiler endotelial, sel otot polos, fibroblas dan extracellular matrix.

Pada pemeriksaan FOB pada penderita didapatkan reaksi inflamasi di daerah sekitar benda asing karina utama, seperti hiperemi mukosa yang sudah minimal.

Diagnosa adanya benda asing pada jalan nafas didasarkan pada riwayat (anamnese), gejala klinis, pemeriksaan fisik, radiologis dan bronkoskopi. 
Dari anamnesa terdapat riwayat pada saat penderita menggigit jarum pentul sambil berbicara kemudian merasa tertelan, penderita mengalami batuk-batuk keras sebentar, namun satu jam setelah itu penderita tidak mengeluh apapun, dari klinis dan pemeriksaan fisik yang didapatkan penderita tidak didapatkan kelainan. Pasien dengan benda asing di bronkus yang datang kerumah sakit kebanyakan berada dalam fase asimtomatik. Batuk merupakan mekanisme perlindungan paru dari aspirasi dan membantu pengeluaran sekresi bronkial yang berlebih. Batuk dapat terjadi karena rangsangan pada reseptor iritan yang terdapat pada laring, trakea, dan bronkus. Rangsangan dapat berupa infeksi,keradangan parenkim dan saluran napas, tumor, benda asing serta kelainan kardiovaskuler. Efektifitas batuk dapat menurun pada :

- Otot pernapasanyang lemah antara lain pada myastenia gravis.

- Reflek batuk menurun pada diabetes melitus dan pemberian obat anti tusif.

- Keadaan paru tidak normal antara lain PPOM dan obstruksi saluran napas.

Pemeriksaan foto toraks posteroanterior dan lateral dapat dipertimbangkan terlebih dahulu, meskipun kebanyakan benda asing radiolusens (90\%). Gambaran obstruktive emfisema, atelektasis, infiltrat dapat dijumpai meski dalam 24 jam gambaran foto toraks tidak memberikan kelainan.

Pada penderita dilakukan foto toraks setelah kejadian, tampak bayangan berdensitas logam pada proyeksi parahiler kiri serta tidak tampak tandatanda emfisema, atelektasis dan infiltrat.

Selanjutnya bronkoskopi diperlukan untuk menegakkan diagnosis dan terapi. Indikasi penggunaan bronkoskopi terbagi dua yaitu indikasi diagnostik dan indikasi terapi. Indikasi diagnostik yaitu :

- Gambaran foto torak abnormal

- Batuk darah yang tidak diketahui penyebabnya

- Batuk persisten dan banyak sputum

- Wheezing lokal

- Benda asing dalam saluran nafas

- Obstruksi bronkus dan atelektasis

- Foto toraks normal, tetapi didapatkan gambaran keganasan pada pemeriksaan sitologi.

Indikasi terapi :
- Mengeluarkan sekret penyebab atelektasis, pneumonia dan abses paru

- Mengeluarkan benda asing

- Tindakan operasi dengan sinar laser, pemasangan stent.

Komplikasi dari bronkoskopi fleksibel adalah :

- Komplikasi akibat premedikasi : depresi pernafasan, hipotensi, sinkop, henti nafas

- Komplikasi akibat anestesi lokal : henti nafas, spasme laring, methemoglobinemia

Komplikasi akibat tindakan bronkoskopi : spasme laring, gagal nafas, pneumonia, pneumotoraks, perdarahan, henti jantung, sinkope, bradikardi, takikardi ventrikel. Pengeluaran benda asing dari saluran pernafasan umumnya dilakukan dengan bronkoskopi, torakotomi adalah pilihan tindakan bila dengan bronkoskopi gagal atau tidak memungkinkan untuk dilakukan.

Pada penderita dilakukan bronkoskopi fleksibel dengan indikasi diagnostik dan terapi yaitu melihat adanya benda asing di saluran nafas sekaligus mengeluarkan benda asing tersebut, dan pada penderita tidak dilakukan torakotomi karena sudah berhasil dilakukan ekstraksi benda asing dengan bantuan FOB.

Komplikasi pengeluaran benda asing dari jalan napas sering terjadi terutama pada anak.Perforasi bronkial adalah hal yang jarang.Adanya benda asing pada bronkus dan trakea dalam waktu lama dapat menyebabkan jaringan parut dan stenosis yang memerlukan tindakan dilatasi dan intervensi bedah. Atelektasis, pneumonitis, atau wheezing merupakan komplikasi yang terjadi pada aspirasi benda asing. Benda asing yang menetap lama pada paru dapat mengikis bronkus dan menyebabkan fokal area dari brokiektasis dan perdarahan yang memerlukan tindakan reseksi paru.

Pada penderita ini aspirasi benda asing sudah berlangsung sejak 14 hari yang lalu tapi penderita datang tanpa adanya keluhan dan berhasil dilakukan ekstraksi benda asing dengan bantuan FOB.

\section{Ringkasan}

Telah dilaporkan penderita Nn. N (14 tahun) dengan keluhan tersedak jarum pentul. Tertelan jarum pentul dialami 14 hari sebelum MRS. Sesaat ketika tertelan, penderita merasakan batuk-batuk hebat, namun satu jam setelah itu penderita tidak 
mengeluh apapun sampai dengan MRS. Penderita sempat berobat ke dokter spesialis paru di Pamekasan, kemudian dirujuk ke RSU Dr. Soetomo. Dari foto toraks didapatkan gambaran jarum pentul pada bronkus kiri yang tidak berubah posisi pada saat difoto ulang berikutnya. Bronkoskopi dilakukan dengan indikasi diagnostik dan terapi pada Nn. N. Tidak didapatkan kontraindikasi untuk dilakukan bronkoskopi maupun torakotomi jika bronkoskopi gagal. Dilakukan ekstraksi jarum pentul yang telah teraspirasi hari keempat belas dengan menggunakan bronkoskopi serat optik pada penderita. Ekstraksi jarum pentul berhasil dilakukan.

\section{DAFTAR PUSTAKA}

D. Passàli, M. Lauriello, L. Bellussi, G.C. Passali, F.M. Passali, D. Gregori. Foreign body inhalation in children: an update. ACTA otorhinolaryngologica ita lica 2010;30:27-32

Nael Al-Sarraf, Hassan Jamal-Eddine, Fatma Khaja, Adel K. Ayed. Headscarf pin tracheobronchial aspiration: a distinct clinical entity. Interactive CardioVascular and Thoracic Surgery 2009 ;1-4

Ahmed Ragab, Osama M. Ebied, Sherief Zalat. Scarf pins sharp metallic tracheobronchial foreign bodies : Presentation and management. Elsevier 2007; 769-73.

Warshawsky EM. Foreign Body Aspiration. E Medicine. 2006.01-09

Dikensoy O,Usalan.C,Filiz.A;Foreign body aspiration :clinical utility of flexible bronchoscopy.pmj.bmj 2002:399-403.

Debeljak.A,Sorli.J,Music.P,Kecelj,P.Bronchoscopic removal of foreign bodies in adult:experience with 62 patiens from 1974-1998.Eur Resp J 1999;14:792-795

Grippi M.A;Upper Airway Obstruction;Fishman×s Manual of Pulmunary Diseases and disrders $4^{\text {rd }}$ edition;2008;605-06

Gold SJ. Anaesthesia for adult bronchoscopy. The Royal College of Anaesthetists.2000.3.110-3.

Hillard T, Sim R, Saunders M, et al. Delayed diagnosis of foreign body aspiration in children Emergency Medicine journal. 2003. 20. 100-1.
Michael PP. Foreign Bodies of the Respiratory Tract. The Internet Journal of Emergency Medicine. 2004. 2. 01-13.

Gurpmar A, Kilic N, Dogruyol H. Foreign Body Aspiration in Children. Turkish Respiratory Journal. 2003. 4. 131-4.

Kikuchi R, Isowa N, Tokuyasu H, Kawaski Y. Intraoperative migration of a nail from the left B10b to the main bronchus. Interactive Cardio Vascular and Thoracic Surgery.2007.6.92-3.

Narasimhan KL, Chowdhary SK, Suri S, et al. Foreign Body Airway Obstructions in Children-Lessons Larnt from a Propective Audit. J Indian Assoc Pediatr Surg. 2002.7.184-9.

Farhat Baharloo, Francis Veyckemans. Tracheobronchial foreign bodies: presentation and management in children and adults. Chest 1999;115:1357-1362

Baratawidjaja KG. Inflamasi. Imunologi Dasar.2004.6.153-71.

Chung-Hua Chen,et.al. Foreign body aspiration in to the lower airwy in Chinese adult: Chest 1997;112:129-133

Crapo D.J, Allen G, Sherman P.M,MussonA.R. Pulmonary immunobiologiand inflamation in pulmonary diseases.Am J Respir Crit Care Med 2000;162:1983-1986Callender T. Laryngo-tracheo-bronchial Foreign Body. 1992.01-05.

Fraser RG,Pare JAP ;Roentgenology of the Airways;Diagnosis of diseases of chest; ${ }^{\text {rd }}$ edtion;1988;36-53

Karen L Swanson, Prakash UBS, Midthun DE, et al. Flexible Bronchoscopic Management of Airway Foreign Bodies in Children. Chest. 2002. 121. 1695-700

Prosedur Tetap Pelayanan Tindakan Medis Kegiatan Non Medis di Unit Perawatan Penyakit Paru. UPF/Lab Ilmu Penyakit Paru Fk UNAIR/ RSU Dr. Soetomo Surabaya. 1997. 01-04.

Schembri K, Scrafimov V, Montefort S, Manche A. Empyema thoracis caused by a foreign body inhaled 30 years previously. Interactive Cardio Vascular and Thoracic Surgery 2003.2.581-3. 
Fishman PA:Cough ;Fishman $\times$ s Manual of Pulmnary Diseases and Disorders $4^{\text {rd }}$ edition ;2008;636-43

Merchant SN, Kirtane MV, Shah KL, et al. Foreign Bodies in the bronchi (a 10 year review of 132 cases). Journal of Postgraduate Medicine. 1984.30.219-23. 